Abstract 159 Tabel 1 Basic characteristics of the study

\begin{tabular}{|c|c|c|c|}
\hline Parameter & $\begin{array}{c}\text { SLAM }<7 \\
(n=19)\end{array}$ & $\begin{array}{c}\text { SLAM } \geq 7 \\
(\mathrm{n}=51)\end{array}$ & p \\
\hline \multicolumn{4}{|l|}{ Sex } \\
\hline Male & 2 & 7 & \\
\hline Female & 17 & 44 & \\
\hline Age (years) & $35(19-63)$ & $30(14-60)$ & 0.22 \\
\hline Duration of discase (ycars) & $2.5(0.33-18)$ & $1.33(0.15-20)$ & 0.16 \\
\hline Hemoglobin $(\mathrm{g} / \mathrm{dL})$ & $12.6(8.93-14.6)$ & $9.50(2.90-13.9)$ & $0.15^{\prime}$ \\
\hline Leukocytes $\left(\times 10^{3} \mu / \mathrm{L}\right)$ & $7.23(3.73-16.38)$ & $6.40(1.02-17.04)$ & 0.96 \\
\hline Neutrophils $\left(x 10^{3} \mu / \mathrm{L}\right)$ & $4.76(11.98)$ & $4.92(0.48-15.52)$ & 0.41 \\
\hline Lymphocytes $\left(\times 10^{3} \mu / \mathrm{L}\right)$ & $1.58(0.66-2.73)$ & $0.95(0.14-3.49)$ & 0.01 \\
\hline Platelets $\left(\times 10^{3} \mu / \mathrm{L}\right)$ & $268(175-370)$ & $220(4.68-687)$ & 0.39 \\
\hline Random plasma glucose $(\mathrm{mg} / \mathrm{dL})$ & $87(73-212)$ & $101(62-232)$ & 0.40 \\
\hline $\mathrm{BUN}^{+}(\mathrm{mg} / \mathrm{dL})$ & $12(7.0-23.3)$ & $13(4-107)$ & $0.73^{\prime}$ \\
\hline Creatinine serum $(\mathrm{mg} / \mathrm{dL})$ & $0.91(0.39-1.32)$ & $0.85(0.32-13.6)$ & 0.08 \\
\hline Albumin (g/dL) & $4.10(2.0)$ & $3.34(1.64-4.35)$ & $0.07^{\prime}$ \\
\hline $\operatorname{ESR}^{++}$(mm/hour) & $23.5(11-82)$ & $47(9-141)$ & 0.41 \\
\hline $\mathrm{CRP}^{*+1}(\mathrm{mg} / \mathrm{dL})$ & $0.70(0.1-3.3)$ & $4.67(0.1-194)$ & 0.00 \\
\hline NLR & $2.87(0.14-9.29)$ & $4.51(0.57-25.85)$ & 0.00 \\
\hline SLICC/ACR Index ${ }^{++++}$ & $0(0-2)$ & $0(0-6)$ & 0.15 \\
\hline \multicolumn{4}{|c|}{$\begin{array}{l}\text { : Blood Ureum Nitrogen } \\
\text { : Erythrocyte Sedimentation Rate } \\
\text { : C-reactive protein } \\
\text { Damage Index } \\
\text { : Adjusted for Disease Activity }\end{array}$} \\
\hline
\end{tabular}

Abstract 159 Tabel 2 Bivariate analysis between several parameters and SLAM score

\begin{tabular}{lcc}
\hline Parameter & SLAM Score & $\mathrm{p}$ \\
\hline NLR & $\mathrm{r:}: 0.249^{\circ}$ & 0.04 \\
Age & $\mathrm{r}:-0.224$ & 0.06 \\
Duration of discase & $\mathrm{r}-0.295^{\circ}$ & 0.01 \\
ESR & $\mathrm{r}: 0.443^{\circ}$ & 0.00 \\
CRP & $\mathrm{r}: 0.319$ & 0.06 \\
\hline
\end{tabular}

$\because$ Significant correlation based on Spearman's Correlation Test (two tail hypothesis, $\mathrm{p}<0.05$ )

$\mathrm{p}<0.01 ; \quad 2.873 \quad(0.14-9.29)$ vs $4.51 \quad(0.57-25.85), \quad \mathrm{p}<0.01]$ Positive correlation was observed between NLR and SLAM score $(r=0.249, \mathrm{p}<0.038)$ with Spearman's correlation test. Analysis with ROC curve revealed the cut-off value of NLR was 3.17 (AUC $0.684, \mathrm{p}<0.02$, 95\% CI $0.55-0.813$, sensitivity $69 \%$, specificity $58 \%$ ).

Conclusions NLR is correlated to disease activity and a promising tool for assessing disease activity in Indonesian SLE patients.

\section{DYSLIPIDEMIA AND DISEASE ACTIVITY IN SYSTEMIC LUPUS ERYTHEMATOUS: AN INDEPENDENT RISK FACTOR}

H Gunawan*, A Awalia, J Soeroso. Airlangga University, Internal Medicine Department Rheumatology Division, Surabaya, Indonesia

\subsection{6/lupus-2017-000215.160}

Background and aims Systemic Lupus Erythematosus (SLE) patients have been associated with increased cardiovascular morbidity and mortality due to atherosclerosis. Dyslipidemia, a traditional atherosclerosis risk factor, has been reported as a long-term independent risk factor in SLE patients. Patients 


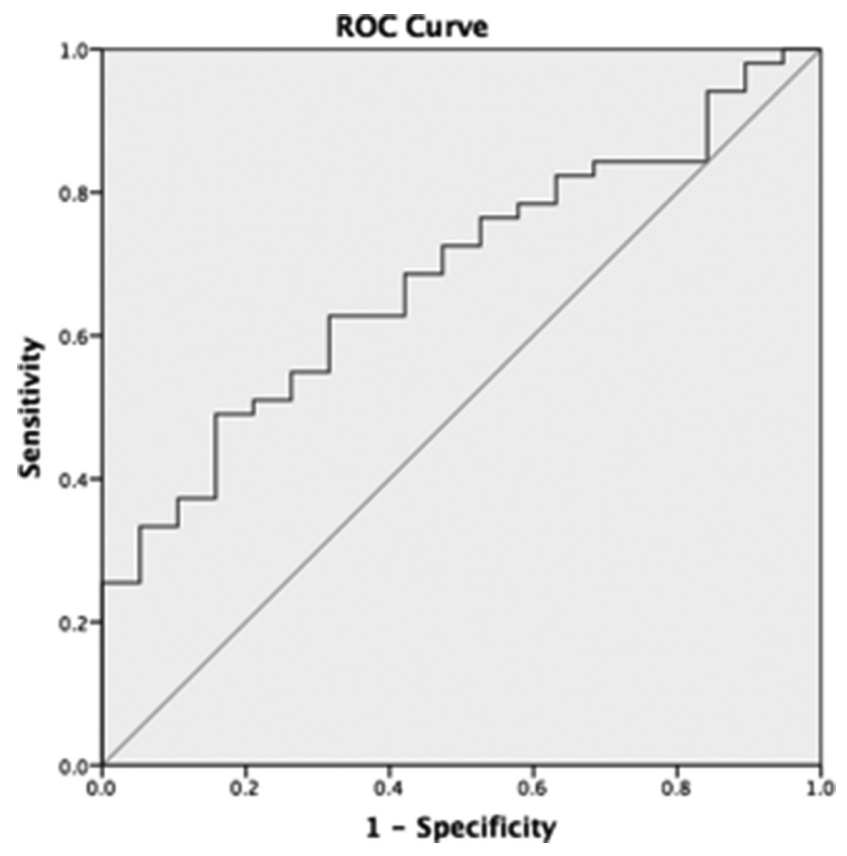

Abstract 159 Figure 1 ROC curve of NLR with activity in SLE patients with high disease activity are in heightened inflammatory state, thus altering their lipid profile and accelerate plaque formation.

To investigate the correlation lipid profile with disease activity in Indonesian SLE patients.

Methods An observational cross-sectional study was conducted in May 2016-August 2016 in Dr. Soetomo Hospital Surabaya involving 73 SLE patients. Disease activity was measured with Systemic Lupus Activity Measure (SLAM) score. Lipid profile was assessed at the time of assessment preceded by 10 hours fasting. Patients with previous history of dyslipidemia and receiving lipid-lowering agents were excluded. Data analysis was done with Spearman's correlation rank test and backward linear regression with SPSS v22.0.

Results There were 21 patients with SLAM score $<7$ (group 1) and 52 patients with SLAM score $\geq 7$ (group 2). Dyslipidemia was more prominent in patients with $0-1$ year's duration group (66.7\%). SLAM Score was positively correlated with triglycerides ( $\mathrm{r}: 0.32, \mathrm{p}<0.00)$ and negatively correlated with HDL ( $\mathrm{r}:-0.57, \mathrm{p}<0.00)$. Analysis with multivariate backward linear regression revealed that HDL and total cholesterol were the independent risk factors influencing disease activity $[\mathrm{F}$ $\left.(2,66)=19.5, \mathrm{R}^{2}=0.35, \mathrm{p}<0.00\right]$.

Abstract 160 Table 1 Basic characteristics of the study based on Disease activity.

\begin{tabular}{|c|c|c|c|}
\hline Parameter & $\begin{array}{c}\text { SLAM }<7 \\
(n=21)\end{array}$ & $\begin{array}{l}\text { SLAM } \geq 7 \\
(n=52)\end{array}$ & $\bar{p}$ \\
\hline \multicolumn{4}{|l|}{ Sex } \\
\hline Male & 2 & 7 & \\
\hline Female & 19 & 45 & \\
\hline Age (years old) & $35(19-63)$ & $30.5(14-60)$ & 0.25 \\
\hline Systole (mmHg) & $120(90-170)$ & $120(80-180)$ & 0.84 \\
\hline Diastole (mmHg) & $80(58-100)$ & $70(50-100)$ & 0.56 \\
\hline Hemoglobin (g/dL) & $12.6(8.93-14.6)$ & $9.55(2.9-13.9)$ & $0.17^{\wedge}$ \\
\hline Leukocytes $\left(\times 10^{3} \mu / \mathrm{L}\right)$ & $7.23(3.73-16.38)$ & $6.40(1.02-17.04)$ & 0.96 \\
\hline Platelets $\left(x 10^{3} \mu / \mathrm{L}\right)$ & $268(122-370)$ & $223.5(4.68-687)$ & 0.41 \\
\hline Random plasma glucose $(\mathrm{mg} / \mathrm{dL})$ & $87(73-212)$ & $101(62-232)$ & 0.46 \\
\hline $\mathrm{BUN}^{+}(\mathrm{mg} / \mathrm{dL})$ & $12(6-29)$ & $13(4-107)$ & $0.50^{\circ}$ \\
\hline Creatinine serum $(\mathrm{mg} / \mathrm{dL})$ & $0.91(0.39-1.32)$ & $0.81(0.32-13.6)$ & 0.08 \\
\hline Albumin $\left(\mathrm{g} / \mathrm{dL}_{3}\right)$ & $4.10(2.4-4.4)$ & $3.33(1.64-4.35)$ & $0.08^{\wedge}$ \\
\hline Total Cholesterol (mg/dL) & $174(120-313)$ & $196(85-427)$ & 0.40 \\
\hline Triglycerides $(\mathrm{mg} / \mathrm{dL})$ & $126.5(71-444)$ & $163(66-777)$ & 0.07 \\
\hline $\mathrm{HDL}^{\circ}$ Cholesterol (mg/dL) & $53.5(27-88)$ & $37(8-71)$ & 0.00 \\
\hline LDL“ Cholesterol (mg/dL) & $95.5(58-159)$ & $108(35-235)$ & 0.31 \\
\hline $\mathrm{ESR}^{++}$(mm/hour) & $25.5(11-82)$ & $47(9-141)$ & 0.41 \\
\hline $\mathrm{CRP}^{*++}(\mathrm{mg} / \mathrm{dL})$ & $0.7(0.1-3.3)$ & $4.67(0.1-194)$ & 0.00 \\
\hline SLICC/ACR Index ${ }^{++++}$ & $0(0-2)$ & $0(0-6)$ & 0.15 \\
\hline \\
\hline \multirow{2}{*}{\multicolumn{4}{|c|}{$\begin{array}{l}* \text { : Erythrocyte Sedimentation R } \\
\cdots \text { : C-reactive protein }\end{array}$}} \\
\hline & & & \\
\hline \multicolumn{4}{|c|}{$\cdots+$ : Systemic Lupus International Collaborating Clinics/American College of Rheumatology } \\
\hline \multirow{2}{*}{\multicolumn{4}{|c|}{$\begin{array}{l}\text { Damage Index } \\
: \text { Statistically significant if } \mathrm{p}<0.05 ; \text { two-tail hypothesis }\end{array}$}} \\
\hline & & & \\
\hline
\end{tabular}




\section{Normal P-P Plot of Regression Standardized Residual}

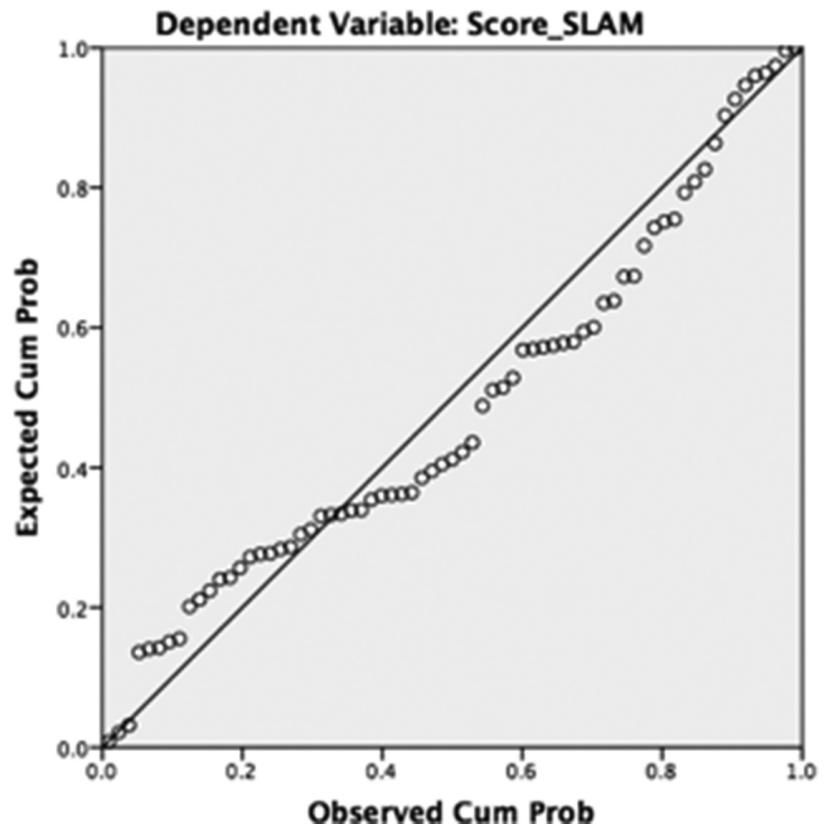

Abstract 160 Figure 1 Normal p-p-plot of regression standardazed residual with dependent veriable

Conclusions: There is a positive correlation between dyslipidemia and SLE disease activity. Total cholesterol and HDL are independent predictor influencing disease activity. Therefore, we recommend lipid profile as a routine examination in SLE patients.

\section{PULMONARY DISORDERS IN LUPUS PATIENT WITH NEPHRITIS}

${ }^{1} \mathrm{Q}$ Guo*, ${ }^{2} \mathrm{Q}$ Hui, ${ }^{1} \mathrm{~S}$ Nan. ${ }^{1}$ Renji Hospital- School of Medicine- Shanghai JiaoTong University, Shanghai Institute of Rheumatology, Shanghai, China; ${ }^{2}$ Renli Hospital- School of Medicine-Shanghai JiaoTong University, Respiratory, Shanghai, China

\subsection{6/lupus-2017-000215.161}

Background and aims To analyse the association between renal histopathological features and chest computed tomography (CT) findings in lupus nephritis (LN) patients.

Methods We reviewed the medical records and chest thin-section CT findings of 152 patients with an established diagnosis of LN based on renal biopsy and 93 systemic lupus erythematosus (SLE) patients without LN between April 2009 and March 2012. The CT images were retrospectively evaluated by an experienced thoracic radiologist without knowledge of the patients' clinical information.

Results Lupus nephritis patients have a significantly higher incidence of lung/plural disease than those without LN. The patients in LN group were more prone to ground glass opacity, interlobular septal thickening, reticular opacities, pleural effusions, and consolidation on CT images than in non-LN group. Class I, III, and IV lupus nephritis were associated with traction bronchiectasis, ground glass opacity, and pleural effusions, respectively. The presence of cord on chest CT scans was significantly associated with renal interstitial lesion and interstitial inflammation/fibrosis. Ground glass opacity and reticular opacities on chest CT were related to renal hyaline thrombi. There was a significant association between pleural effusions and cellular/fibrous crescents, interstitial lesion, or interstitial inflammation/fibrosis. Hyaline thrombi in renal biopsy was an independent risk factor of the presence of ground glass opacity on CTs with logistic regression analysis. Conclusions There are some relation between lung and renal disorders in lupus patient. LN patients were more likely to suffer from lung/pleural disease. The patients with hyaline thrombi in renal biopsy were more prone to have ground glass opacity on CTs.

Abstract 160 Table 2 Basic characteristics of the study based on duration illness

\begin{tabular}{|c|c|c|c|c|}
\hline Parameter & $\begin{array}{r}0-1 \text { Year } \\
(\mathrm{n}=27)\end{array}$ & $\begin{array}{c}1-5 \text { years } \\
(\mathrm{n}=29)\end{array}$ & $\begin{array}{c}>5 \text { years } \\
(n=17)\end{array}$ & $\mathbf{p}$ \\
\hline Dyslipidemia (n) & $18(66.7 \%)$ & $17(58.6 \%)$ & $9(52.9 \%)$ & $0.54^{\circ}$ \\
\hline Total Cholesterol (mg/dL) & $196.5(104-427)$ & $164(85-309)$ & $206(120-346)$ & $0.16^{\prime}$ \\
\hline Triglycerides (mg/dL) & $184(70-777)$ & $137.5(66-453)$ & $160(66-444)$ & 0.48 \\
\hline HDL Cholesterol & $36(8-76)$ & $43(19-70)$ & $49(20-88)$ & 0.08 \\
\hline LDL Cholesterol & $114(36-199)$ & $95.5(35-204)$ & $108(64-235)$ & 0.28 \\
\hline Use of corticosteroid (n) & $23(85.5 \%)$ & $29(100 \%)$ & $16(94.1 \%)$ & - \\
\hline Corticosteroid dose ( $\mathrm{mg} /$ day) & $24(4-50)$ & $4(2-48)$ & $4(2-16)$ & $0.00^{\prime}$ \\
\hline Use of Chloroquine (n) & $14(51.9 \%)$ & $11(37.9 \%)$ & $5(29.4 \%)$ & - \\
\hline Use of Azatioprine (n) & $9(33.3 \%)$ & $5(17.2 \%)$ & $4(23.5 \%)$ & - \\
\hline Azatioprine dose (mg/day) & $100(50-100)$ & $100(50-100)$ & $100(50-100)$ & $0.58^{\prime}$ \\
\hline Use of Ciclosporine (n) & $4(14.8 \%)$ & $14(48.3 \%)$ & $7(41.2 \%)$ & - \\
\hline Ciclosporine dose (mg/day) & $100(50-200)$ & $100(50-200)$ & $100(50-100)$ & $0.56^{\prime}$ \\
\hline SLAM Score & $14(2-31)$ & $7(0-25)$ & $9(1-19)$ & 0.02 \\
\hline SLICC/ACR Score & $1(0-6)$ & $0(0-2)$ & $0(0-5)$ & $0.01^{\prime}$ \\
\hline
\end{tabular}

